\section{INSPIRING PEOPLE TO ADOPT BETTER HABITS}

Oral-B is on a mission to educate the UK on the importance of a good oral health routine, after research found that one in three families (33\%) in the UK are in dental crisis, following a lack of dental care in the last 12 months. Oral-B have launched a

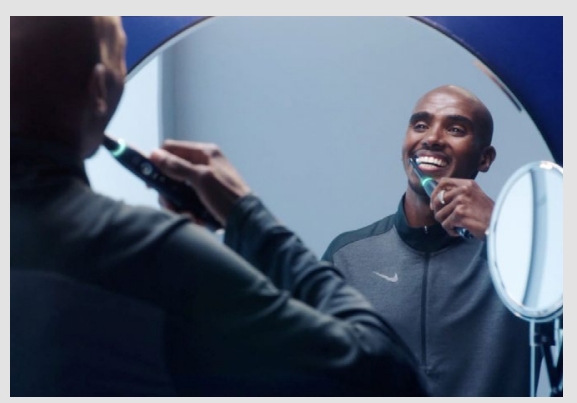

new TV advert featuring multiple Olympic, World and European Champion Athlete and dad of four, Sir Mo Farah CBE, who knows all about the importance of keeping teeth in good condition. A few years ago Mo had a serious tooth infection which saw him admitted to hospital and miss a period of training. Mo is partnering with Oral-B to help raise awareness of the importance of good oral health and to inspire the nation to adopt better oral care routines at home.

Oral-B is proud to partner with Mo Farah to improve the oral health of the nation, by inspiring people to adopt better oral care habits from an early age and to \#BrushLikeAProWithMo.

\title{
RECOMMEND SUSTAINABLE PRODUCTS TO YOUR PATIENTS
}

In the dental practice, reducing waste can be hard when infection control protocols require some items to be disposed of immediately after use, or washed after one wear.

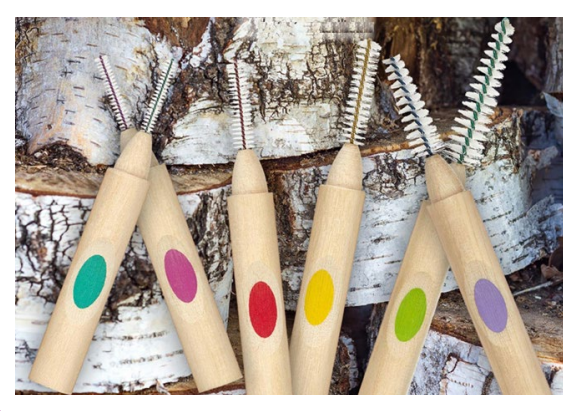

But we can still live more sustainably, by looking at the products we use and recommend. Forest Stewardship Council (FSC) certification enables the identification of wood and paper made with materials from responsibly-managed forests. From TANDEX, the WOODI interdental brush has a handle made from FSC-certified birchwood - the box is fully recyclable too. TANDEX has long supported environmental concerns. To find out more about this, and the WOODI, contact TANDEX today.

For more information on Tandex's range of products, visit https://tandex.dk/.

\section{FEEL GREAT INSIDE AND OUT}

Patients are increasingly on the lookout for what does good and feels good, rejecting harsh chemicals and animal-based products in favour of plant-power and herbal heroes. $\mathrm{BE} Y O U$ gentle whitening toothpaste from Curaprox is the natural partner to their toothbrush - making them feel great inside and out.

Saying no to microplastics, Triclosan, SLS, and animal products, BE YOU celebrates herbal healing and promotes vegan vibes for those looking to bring pure joy to their day-to-day brushing. Chemical nasties give way to the power of glucose oxidase - an enzyme so natural that bees use it to keep germs away from their honey.
In this kind but mighty toothpaste, herbs and natural ingredients such as extracts of echinacea, bitter orange, devil's claw and Indian pennywort, combine beautifully to nourish the mouth's tissue and help stop inflammation.

Available in six zesty, fresh flavours and in a collection of funky colours, let your patients try the power of plants in BE YOU toothpaste today. For more information, call 01480 862084, email info@curaprox. co.uk or visit www.curaprox.co.uk.
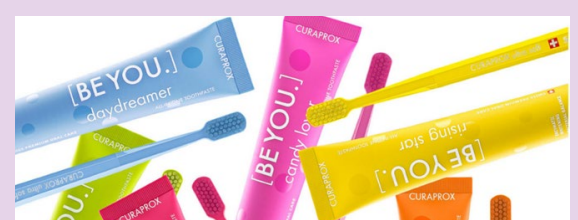

\section{A SIMPLE CHOICE OF AIR PURIFIER}

With so many air purifiers available on the market, it can be difficult to identify which is the best solution for you. The JADE Air Purification System from Nuview makes the choice simple.

It is a medicalgrade unit featuring six-stage filtration and sterilisation technology, enabling it to remove a wide range of indoor air pollutants - from dust, pollen and volatile organic chemicals (VOCs),

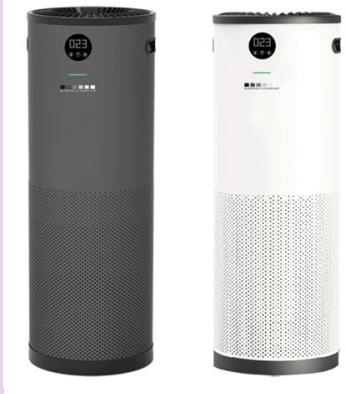
to mould, allergens,

viruses, odours and bio-aerosols.

Operating at an industry-leading low sound level of $\angle 50 \mathrm{db}$, the JADE system ensures efficient flow of clean air throughout the room with its innovative top air outlet. For more information call Nuview on 01453 872266, email info@ nuview-ltd.com or visit www.nuview.co.uk.

\section{MOISTURISING PROTECTION FOR YOUR HANDS}

Many handwashes and hand sanitisers can dry out skin, removing its natural oils and creating dry, cracked areas that could be prone to infection.

Help to protect the hands of your patients and staff with the Steri-7 Xtra hand preparation solution range from Initial Medical, which includes hand rub and wash. These products offer exceptional protection and kill $99.99 \%$ of pathogens including Coronavirus [tested against feline Coronavirus, a surrogate virus for Coronavirus] and stay active for up to three hours after application [Source: Steri-7]. They offer a high level of hygienic protection to anything from pre-operative surgical scrubs to general use in kitchens, washrooms and toilets.

Hand safe and dermatologically tested, the solutions are also moisturising and nourish the hands as they protect, making them the perfect option for repeated use.

For further information visit www. initial.co.uk/medical or Tel: 08708504045 . 